Vanya Valkadinova, $P h D^{*}$

Judge, Administrative Court of

Blagoevgrad, Blagoevgrad,

Lecturer at the National Institute of Justice, Sofia, the Institute of Public Administration, Sofia, the Lawyer Training Centre Krastyo Tsonchev, Sofia, Bulgaria
ОРИГИНАЛНИ НАУЧНИ РАД

doi:10.5937/zrpfni1879181V

UDK: 340.132(497.4:4-672EU)

Рад примљен: 30.09.2018.

Рад прихваћен: 23.10.2018.

\title{
THE PRINCIPLE OF PROPORTIONALITY IN THE APPLICATION OF SANCTIONS AND OTHER MEASURES OF STATE COERCION ACCORDING TO BULGARIAN LEGISLATION AND EUROPEAN UNION LAW ${ }^{* *}$
}

\begin{abstract}
Proportionality, as a basic principle for exercising the state competences, requires that acts of public authority do not affect rights and legitimate interests to a greater extent than it is necessary for the purpose for which the act is issued. In applying sanction and other state coercion measures, the principle of proportionality is a threshold for the limitation of fundamental rights. Sanctions must be effective, dissuasive and proportionate. Their imposition must not have consequences which are manifestly incompatible with the objective pursued. These other requirements, which are closely related to sanctions, must be met by state coercive measures that ensure their effectiveness. The study focuses on proportionality as an element of judicial control in the definition and control of state coercive measures in domestic law and in European Union law.
\end{abstract}

Key words: proportionality principle, sanction, coercive administrative measures, judicial review of proportionality.

\footnotetext{
*vvalkadinova@mail.bg

** This paper was presented at the International Scientific Conference "Law in the context of addressing the Challenges of the Contemporary World", held at the Faculty of Law, University of Niš, on $13^{\text {th }}-14^{\text {th }}$ April 2018.
} 


\section{Introduction}

Criminal justice policy is, as a rule, sovereign power of states. States' social values protected by the criminal justice systems are closely linked to the very identity of societies within them. Therefore, the definition of categories of offenses and administrative offenses is a matter for the national authorities. According to Article 83 (2) of the Treaty on the Functioning of the Union (TFEU), European Union (EU) legislation on the definition of offenses and sanctions is limited to ,minimum rules' (description of conduct considered to be criminal, requirements for a type of sanction or valid for EU-wide definition of what should be regarded as aggravating or mitigating circumstances), where the approximation of the laws and regulations of the Member States in the field of criminal law is indispensable in order to ensure effective implementation of a Union policy in an area which has been subject to harmonization measures. This restriction excludes full harmonization. However, any Member State legislation which protects fundamental rights by means of criminal sanctions should be based on the principle of proportionality (Article 5 (4) of the Treaty on European Union (TEU): the means of action chosen by the national authorities must be necessary to achieve the objectives that they pursue.

Pursuant to Article 3 (2) TEU, the Union grants its citizens an area of freedom, security and justice without internal frontiers in which the free movement of persons is ensured, together with appropriate measures with regard to the control of external borders, asylum, immigration, and prevention and fight against crime. To achieve this goal, Member States have freedom in setting sanctions, but it is not complete. The principle of loyal cooperation under Article 4 (3) TEU requires the Member States to take all measures which are appropriate to ensure the scope and effective operation of European Union law, and to that end, while retaining their discretion as to the choice of such measures, they must ensure that they in all cases give the penalty an effective, proportionate and dissuasive character ${ }^{1,2}$ National legislation must not obstruct the exercise of rights and obligations under European Union (EU) law by directly or indirectly making them difficult or impossible to enforce through domestic remedies. Restrictions on the rights and freedoms recognized by the Charter of Fundamental Rights of the European Union (the Charter) may only be imposed if they are necessary and meet objectives of general interest recognized by the Union or the need to protect the rights and freedoms of others. According to Article 49 (3) of the Charter, the severity of the punishable offenses should not be disproportionate to the offense. The introduction of excessively severe sanctions can be interpreted as a disguised restriction on the freedoms recognized by

1 Case C-382/09 S. M. S., ECLI:EU:C:2010:596.

2 Case C-201/10 Urbán, EU:C:2012:64, т. 23. 
EU law. ${ }^{3}$ In a comment on "internal order“, the Court of Justice of the European Union (CJEU) points out that, when regulating the internal order, the measures cannot be exceeded in the light of Union Legal, to what extent this guarantees the free movement of goods, people, services and capital. ${ }^{4}$ In that connection and in the judgment of the General Court of 17 March 2016 in Case T-817/14 (paragraph 50), it is recalled that, the principle of proportionality, which is part of the general principles of European Union law and reproduced in Article 5 (4) TEU, requires that the acts of the Union institutions should not go beyond what is appropriate and necessary to achieve the legitimate aims pursued by the legislation in question, bearing in mind that, where there is a choice between several appropriate measures, it is appropriate to resort to the measure which creates the fewest constraints, and the inconveniences caused by it must not be disproportionate to these objectives". ${ }^{5}$

Similar is the understanding of the content of the principle of proportionality and the practice of the European Court of Human Rights (ECtHR). Although the European Convention for the Protection of Human Rights and Fundamental Freedoms (the ECHR) does not use the term "proportionality“, the principle is particularly clear in the provisions guaranteeing the right to private and family life, housing and correspondence (Article 8), freedom of religion (Article 9), freedom of expression (Article 10), and freedom of association (Article 11). States have a margin of appreciation of the necessary restrictions on fundamental rights (with the exception of absolute rights ${ }^{6}$ ) to protect the public interest, but the interference or limitation of the right must be "necessary in a democratic society". The frameworks of State intervention are determined by the criteria set out in the Convention, consistently maintained in a number of decisions of the ECHR: the measures provided for by the law to be necessary in a democratic society in the interests of national and public security or the economic wellbeing of the country, to prevent disorder or crime, to protect health and morals, or the rights and freedoms of others, to pursue a legitimate aim and to achieve

3 Case C-255/14 Chmielewski, EU:C:2015:475.

4 Case C-273/97 Sirdar (Angela Maria) v The Army Board and Secretary of State for Defence [1999], ECR I-7403.

5 Case C-343/09 Afton Chemical, EU:C:2010:419; Joined Cases C-581/10 and C-629/10 Emeka Nelson and Others v Deutsche Lufthansa AG, EU:C:2012:657; Case C-283/11 Sky Österreich GmbH v Österreichischer Rundfunk, EU:C:2013:28; Case C-101/12 Herbert Schaible, EU:C:2013:661.

6 As a rule, the ECHR is consistent that the state can not restrict absolute rights and does not investigate the proportionality of such interference (Case Gäfgen v. Germany, App no 22978/05 (ECtHR 1 June 2010); Case Siliadin v France, App no 73316/01 (ECtHR 26 July 2005). 
a reasonable balance between the means used and the objective, whitch achievement is sought. ${ }^{7}$

In the Bulgarian legal system, proportionality is a constitutional principle, provided in the second paragraph of the Preamble of the Constitution of the Republic of Bulgaria (CRB) as one of the „universal values“. The rule of law under Article 4 paragraph 1 of the $\mathrm{CRB}$ requires the proportionality of the legal restrictions imposed on individual rights and freedoms protected by the CRB. They must be appropriate, possibly „the smoothest" and at the same time effective enough means to achieve the constitutionally justified objective. ${ }^{8}$ The proportionality requirement is applied as the decisive criterion for the type and size of legal restrictions and for the determination of specific limits on the exercise of fundamental rights (Drumeva, 2008). In terms and content, the established constitutional criteria for the admissibility of interference are identical to those established in the ECHR and the Charter and those adopted in the practice of the ECHR and the CJEU human rights standards.

\section{Proportionality as an element of judicial control}

Proportionality is an element of judicial control in the determination and control of state coercive measures (irrespective of the division of state coercive measures of sanction as the legal consequence of an offense, ${ }^{9}$ the implementation of which leads to the sanctioning (most often punishment) of the perpetrator in criminal law, administrative sanctions and impact measures, including coercive administrative measures, ${ }^{10}$ as substantive law institutes in the various legal sciences to which our attention is directed), which includes

7 Case Sidabras and Others v. Lithuania, App no 50421/08 (ECtHR 23 June 2015.); Case Oleksandr Volkov v. Ukraine, App no 21722/11 (ECtHR 9 Jan 2013); Case Riener v. Bulgaria, App no 46343/99 (ECtHR 23 May 2006).

8 Decision No 14 of 4 November 2014 of the Constitutional Court of the Republic of Bulgaria on Constitutional Case No 12/2014

9 According to the commonly accepted definition, the offense constitutes guilty unlawful act or omission (aggregated by the term "act") with a socially or socially detrimental effect, the execution of which is usually accompanied by a legal sanction or other legal consequences for the perpetrator (Boichev, 2003; Ganev,1990).

10 In Article 22 of the Administrative Violations and Penalties Act, the purpose of the compulsory administrative measures is defined as a legal means of Sanctions Act of the Republic of Bulgaria preventing and abolishing the administrative violations as well as for preventing and remedying the harmful consequences thereof. The compulsory administrative measure protects a particular rule of law by aligning its disposition with the conduct of a particular legal entity which is immediately threatened with diversion, deviation or deviation from the prescribed (Decision No 10 of 29 May 2018 of the Constitutional Court Constitutional Court of the Republic of Bulgaria on Constitutional Case No. 4/2017). 
several steps: legitimacy - legality (in detail, Stoynov, 1999), suitability, necessity and proportionality in a narrow sense. Illegitimacy is generally ruled out for a state sanction. At constitutional level, the CRB explicitly proclaims the nullum crimen sine lege principle, but not the principle nulla poena sine lege ${ }^{11}$ although the proclamation of the first necessarily implies the protection of the latter (Dolapchiev, 1994, Girginov, 1999). A number of authors draw it out of the norm of Article 4 paragraph 1 of the CRB (Nenov, 1992), according to which Bulgaria is a rule of law and its element is precisely the principle of proportionality of the crime and the punishment, as well as the norm of Article 5 paragraph 3 of the CRB (Stoynov, 1999), which contains the classic principle "No one can be convicted of an act or omission, which was not declared by the law for a crime at the moment of its execution". In the Bulgarian legal system, the measures of state coercion are formally defined and can be regulated only in a normative act having the rank of a law (Article 5 paragraph 3 of the CRB). The rationale for applying the state coercion, the subjects and the objects of coercion, the measures of impact in which it is expressed, and the order for their implementation are normative.

From the point of view of legitimacy, state intervention should be „prescribed by law", but national legislation should also provide sufficient safeguards against arbitrary interference with fundamental rights. State enforcement (criminal law, administrative law) should also be a means of pursuing the intended purpose of its implementation and, moreover, be an appropriate means of achieving that objective - the public interest which calls for the implementation of State interference. Given the broad discretion enjoyed by the legislature in the regulation of State coercive measures, the purpose of the control is to prevent the application of inappropriate measures to achieve a specific legitimate aim, such as the manifestly inappropriate nature of the measure; in light of the objective which the legislature intends to achieve, its application may affect its legality. The question is not whether the measures adopted by the legislator are the only or the best possible but whether they are appropriate and necessary in relation to the objective pursued. In that regard, according to the CJEU, where European Union law does not contain more precise rules on the fixing of national penalties since it does not explicitly provide for criteria to assess the proportionality of such sanctions, ,sanctioning measures under national law must not exceed the limits of is appropriate and necessary to attain the objectives legitimately pursued by that legislation, given that, where there is a choice between several appropriate measures, the least binding and recourse must be had to the facilities

11 The principle is proclaimed in Article 2, paragraph 1 of the Criminal Code of the Republic of Bulgaria and in Article 3, paragraph 1 of the Administrative Violations and Sanctions Act of the Republic of Bulgaria. 
should not be disproportionate to the aims pursued. ${ }^{12}$ In this context, the CJEC considers that the severity of sanctions should be in line with the severity of the offenses punished by them, including by ensuring a genuine deterrent effect, while respecting the fundamental principle of proportionality. ${ }^{13}$

Proportionality in the strict sense in the field of state coercion is a test of whether the objective can be achieved by alternative measures that lessen the freedom or interests of others (disqualification by giving notice of minor offenses where the punishment that may be impose a disproportionate burden on the perpetrator). Judicial control of proportionality implies the appropriateness and necessity of the measure but, within this framework, the objective and the measure are compared to resolve the conflict between the public interest in protection against offenses and the opposite private interest of the offenders affected by the state intervention.

In the field of enforcement of state coercive measures (penalties for offense and administrative offense and administrative coercive measures - coercive administrative measures) the judicial control of proportionality does not rest exclusively on subjective perceptions. According to the case-law of the CJEU, the principle of proportionality is binding on the Member States, which are obliged ,not only to lay down rules on the gravity of fines but also to assess the factors which may be taken into account in setting the fine. ${ }^{14}$ Penalties and measures of administrative coercion should adequately reflect the nature, gravity and consequences of the offense, and judicial review should reasonably assess all the facts. Assessing which measures are effective, proportionate and dissuasive on a case-by-case basis should reflect the objective pursued by the chosen measure - restoring compliance or sanctioning unlawful behavior (or both). Due to the different procedural order and the different nature of the activity of imposing sanctions (criminal and administrative), which may be imposed by the order of the Criminal Procedure Code (CPC) of the Republic of Bulgaria, by a sentence and by the order of the Administrative Violations and Sanctions Act (AVSA) of the Republic of Bulgaria on the application of administrative enforcement measures (compulsory administrative measures), the Administrative Procedure Code (APC) of the Republic of Bulgaria envisages the issuance of an individual administrative act by means of which the legislator may establish different criteria for proportionality control and envisage the judicial control by the Court.

12 Case C-210/10 Urbán, EU:C:2012:64, т. 24 и 53.

13 Case C-565/12 LCL Le Crédit Lyonnais, EU:C:2014:190, т. 45.

14 Case C-210/10 Urbán, EU:C:2012:64, т. 54. 


\subsection{Proportionality in imposing penalties}

The specific criminal procedure manifestation of the principle of proportionality is the provision of Article 31 paragraph 4 of the CRB, according to which „There are no restrictions on the rights of the accused beyond what is necessary for the implementation of justice". Although the provision refers only to prisoners, there can be no doubt that the requirement is applicable to other penalties. Both the offense and any other punishment and the exercise of administrative coercion in the enforcement of coercive administrative measures cannot be aimed at causing physical suffering or humiliation of human dignity (Article 36 (2) of the Criminal Code (CC) of the Republic of Bulgaria.

The basic rule for determining the punishment under Article 54 paragraph 1 of the CC and under Article 27 paragraph 1 of the AVSC obliges the court and the administrative authority to determine the penalty within the limits provided by the law for the committed crime or administrative violation. The type and amount of the punishment are specified in the sanction of the relevant norm in the Special Part of the CC or in a special law in whose disposition the administrative violation (legal status) is outlined.

Outside of the law, the punishment should be the offense and the administrative offense (Article 35 (1) of the CC and Article 27 (1) of the AVSC), respectively. The type and severity of the offense, defined in principle on the basis of the general and abstract characteristic of the act, outlines the varying degree of interference (the type of punishment), while the severity of the punishment is more caseoriented with all its peculiarities. An effective, proportionate and dissuasive response to an infringement depends on the circumstances of the case. The proportionality of the penalty is reflected in the mandatory requirement of the law to determine the degree of public danger of the act (nature, severity and duration of the offense) and that of the perpetrator, the form of guilt (intent or negligence), the inducement to commit the act and any other mitigating and aggravating circumstances (damage suffered, the co-operation of the offender to limit the consequences of the offense or offense for the person concerned or persons related to the previous damages, directly or indirectly realized financial benefits, etc. - Article 54 paragraph 1 of the CC and Article 27 paragraph 2 of the AVSC) except for those which are taken into account by law in determining the offense or administrative offense. Determining the punishment according to the aggravating and attenuating circumstances is a matter of discretion, inasmuch as the law does not state exhaustively the aggravating and mitigating circumstances - as defined, objective and predetermined signs of the act, the perpetrator or the reality. However, this discretion has its limits - the limits of the penalty at the minimum and maximum set. In all cases, the court and the 
administrative prosecuting authority cannot impose a penalty heavier than the maximum prescribed. According to Article 7 item 1 of the ECHR, to which Bulgaria is a party, one shall not receive a more severe punishment than the one provided for the respective offense at the moment when it was committed. They cannot impose a penalty for an administrative offense committed and under the minimum stipulated (Article 27 (5) of the AVSC), but for a criminal offense where the legislator has envisaged the possibility for the court to impose a lighter punishment under certain hypotheses (Article 55 and Article 58 of the CC). The criteria introduced by the legislator for the proportionality of the punishment are cumulative, and through them the law allows for the specific punishment to be determined taking into account all individual peculiarities of the committed crime or administrative violation. The punishment should adequately reflect the nature, gravity and consequences of the offense or violation. It should be commensurate with the severity and achieve individual and general prevention.

\subsection{Proportionality in the application of administrative enforcement measures}

In the exercise of administrative coercion by enforcement of coercive administrative measures (hereinafter referred to as „coercive measures" or "measures"), the administrative body is bound by the requirements for the legality of the individual administrative acts laid down in the provision of Article 146 of the APC as grounds for challenge, one of which is the conformity of the act with the purpose of the law: the coercive administrative measure can only be applied in the absence of any other means of achieving its outcome and only for the purpose the legislator had in mind exercising state coercion. Within the framework of the requirement for compliance of the measure for the implementation of the measure with the purpose of the law, the judicial control of its proportionality shall also be exercised.

The judicial review of the lawfulness of the administrative act is complete and requires the court's discretion as to the conformity of the act with the purpose of the law (and in the absence of a complaint on that ground) ${ }^{15}$ the coercion should only be directed to the immediate purpose of the measure, to ensuring the positive actions of the entity in the legal relationship and to abstain from the legally forbidden. Criteria for this assessment are legally established by the provision of Article 6 of the APC. Proportionality (also known as the principle of proportionality) in the exercise of powers to issue administrative

15 The obligation for the court is legally assigned by the provision of Article 168 (1) APC, according to which the court is not limited only to discussing the grounds stated by the challenger, but is obliged, on the basis of the evidence presented by the parties, to verify the lawfulness of the contested administrative act on all grounds under Article 146 APC. 
acts by the administrative bodies is a basic principle in the administrative process explicitly proclaimed in the provision of Article 6 of the APC, which is characterized by three aspects of the judicial control: a) suitability - the measure is appropriate to achieve the objective; b) necessity - there should be no less restrictive means to achieve the same objective, and c) proportionality in the strict sense - balance the benefit of achieving the target against the burden on the addressee of the measure. The choice of the lightest coercive measure is not a matter of administrative discretion. The Authority is obliged to apply the lightest measure and to achieve the purpose of the law. The extent to which the restrictive measure taken is proportionate to the interest protected is a question of the lawfulness of the implementing measure because the limitation of subjective rights will be in line with the requirements of law if it has the effect of achieving the legal objective. This verification is possible only through the assessment of compliance with the criteria under Article 6 of the APC. Their violation may serve as a ground for revoking the enforcement measure only on this basis - Article 146, item 5 of the APC.

\section{Legal consequences of breach of the principle of proportionality}

The question of the proportionality of the penalty and the coercive administrative measure can arise, on the one hand, as a question of the necessity of their normative establishment and, on the other, as a question of the lawfulness of their application (the lawfulness of issuing and enforcing the acts with which the penalties measures are taken). The different procedures for the issuance of punishments and the enforcement of coercive administrative measures also determine a different legal remedy against these acts.

The Bulgarian legislator has raised the disproportionality of the punishment as a ground for challenging court acts (court acts and acts of courts with powers to impose administrative penalties (punitive decrees)), the so-called „obvious injustices" of the punishment imposed. The verdict and the court decision on administrative sanction are subject to amendment by cassation order (Article 348, paragraph 1, item 3 and paragraph 5, item 1 of the CCP) only for obvious injustice of the punishment, when it obviously does not correspond to the public danger of the act and the perpetrator, the mitigating and aggravating circumstances, as well as the purposes of Article 36 of the CC and Article 12 of the AVSC. It is the court which is to monitor compliance with the proportionality requirements and may amend the sanction imposed by reason of disproportionality or cancel the act of imposing it by replacing it with other impact measures. In the application of administrative enforcement measures with the issuance of an individual administrative act, the person concerned may 
challenge the act only on grounds of the non-pro-rata nature of the measure, as the jurisdiction of the court is to cancel it as part of the control of compliance of the act with the law (Article 146 item 5 of the APC). More complex is the question of the proportionality of the legal provision itself, which provides for the imposition of criminal or administrative measures on state coercion whether the restrictive measure will directly achieve and will guarantee the protection of the public interest compared to the intended value in whose defense it is accepted. This assessment is not only a question of the constitutionality of the law, which is the exclusive competence of the Constitutional Court of the Republic of Bulgaria, but also a question of compliance of the Bulgarian law with the principles of EU law, which may arise before the national court. This issue is particularly acute when it comes to cumulation of various measures of state coercion towards a person. Due to the fact that the coercive administrative measures are not sanctions under Bulgarian law, it is possible to cumulate them with administrative or capital punishment in cases where the grounds for applying a coercive measure are an offense (administrative offense or crime). Defined in Article 22 of the AVSC, the purpose of compulsory administrative measures opens the possibility for the legislator to freely extend the hypotheses in which the use of coercive measures is envisaged as a means of achieving the fulfillment of the administrative obligations or for achieving the objectives of the administrative punishment. The trend is a growing number of normative acts which provide for the enforcement of coercive measures along with the punishment of certain unlawful behavior. This trend also raises the necessity of controlling the proportionality of the normative act itself: whether the legislative objective that determined the adoption of the disputed provisions is legitimate from the point of view of the basic law of the country and whether the introduced restriction is a necessary, appropriate and proportionate legal instrument of the lawful result in the conditions of a democratic society, which has to protect in a balanced way the rights and freedoms of all its members. The violation of the principle of proportionality in the issuing of the relevant instruments for the enforcement of state coercive measures results in the unlawfulness of the specific interventions as unconstitutional. However, insofar as Bulgarian law does not provide for any special procedural means of responding to the constitutional appeal (Verfassungsbeschwerde) in German law, the breach of the principle of proportionality is invoked by ordinary procedural means - an appeal to the court, which is constitutionally settled and validated in separate provisions of a law. In such a complaint, the Supreme Court of Cassation of Bulgaria or the Supreme Administrative Court of Bulgaria (Article 150, para. 1 of the CRB) may refer the matter to the Constitutional Court of the Republic of Bulgaria to declare unconstitutionality in cases where the law can lead to an unjustified restriction of fundamental rights, or the national court may refuse 
to apply the national law affecting the fundamental rights by referring to the ECHR whose norms have primacy over the rules of domestic law that contradict them (Article 5, para. 4 CRB).

However, proportionality as a matter of the need for the statutory establishment of state coercion measures for an offense has another dimension since the judgment of the Court of Justice of 16 July 2015 in the Chmielewski case (C255/14) whereby the CJEU has established binding rules on the assessment of a penalty as "proportionate" where this penalty applies to a breach of European law. The preliminary ruling has a direct practical significance for enforcement by national courts since in the future the national judge is faced with the challenge of complying with both European and national legislation in defining a criminal offense having a cross-border dimension or a direct negative impact on the effective implementation of policy of the Union in an area which is subject to harmonization measures. The CJEU takes note of the lack of harmonization in the field of sanctions, which empowers Member States to choose the appropriate sanctions but recalls that, according to the settled caselaw of the Court ${ }^{16}$ they are required to exercise their competence in compliance with European Union law and its general principles and, consequently, with the principle of proportionality. In this context, the CJEU stated that the severity of the sanctions must be in line with the gravity of the infringements inflicted with them, including by ensuring a genuine deterrent effect while respecting the fundamental principle of proportionality. ${ }^{17}$ Therefore, in the light of the C-255/14 judgment, national law must be interpreted in such a way as to ensure that the objective of ,proportionate punishment' is attained, including in the event of a disproportionate national provision providing for the penalty in question, should reject its application, referring to the principle of primacy of EU law over the domestic law of the Member States (Article 249 (2) of the Treaty Establishing the European Community (TEC)). ${ }^{18}$ The CJEU expressly stated that the national court ,... must, as far as possible, interpret the internal legal framework which it is to apply in accordance with the requirements of European Union law... Where the result achieved by European Union law cannot be attained by interpretation of domestic law, in accordance with European Union law, national courts are required, in particular, to ensure that the provisions of European Union law are fully effective and, where necessary, on their own initiative, disapply any

16 Case C-430/05 Ntionik and Pikoulas, EU:C:2007:410, т.53; Case C-210/10 Urbánq EU:C:2012:64, т.23.

17 Case C-81/12 Asociația Accept, EU:C:2013:275, т. 63; Case C-565/12 LCL Le Crédit Lyonnais EU:C:2014:190, т. 45.

18 Case 6/64 Flaminio Costa v. E.N.E.L., ECLI:EU:C:1964:66, in which the CJEU treats this principle as applicable not only to regulations but to EU law as a whole. 
national provision intraperitoneal law that contradict them. "19 ,Within its jurisdiction, each court or tribunal has the duty to apply Community law in its entirety and to protect the rights which it confers on individuals, leaving aside any provisions of domestic law which conflict with it, whether or not they precede or follow the Community legal norm“. ${ }^{20}$ Furthermore, , the national court entrusted, in the exercise of its competence, with the application of the rules of European Union law, is required to ensure the full effectiveness of those rules by deciding, if necessary, to disapply a national provision which is contrary to them ... and it is not necessary to require or to await the abolition of this provision by legislative or other constitutional order. In fact, any provision of a national legal system, including constitutional status, and any legislative, administrative or judicial practice that may reduce the effectiveness of European Union law because it refuses competent to apply that law court power at the very moment of application to does everything necessary to exclude the application of national legal provisions which may constitute an obstacle to the full effect of Union rules is incompatible with the requirements arising from loneliness the nature of European Union law‘. ${ }^{21}$

\section{Conclusion}

State coercive measures can have a significant restrictive impact on citizens rights. In criminal law, the general principle of proportionality (Article 5 (4) TEU) requires Member States to use them as the last instrument (Article 49 (3) of the Charter). The national legislator should consider what measures and criminal, administrative or civil sanctions would be necessary and sufficient to achieve the legitimate aims pursued by European Union law. Member States are obliged not to allow in their national legislation rules which would conflict with European Union law. Failure to comply with this commitment is of particular importance to the role of the national court. The court respects and enforces the law as it is, but the principle of primacy of European Union law over national law obliges the court, in case of collision, to protect the rights that individuals derive from European Union law. This paper has focused on the proportionality as an element of judicial control and control of state coercive measures, and particularly on identifying the challenges arising from the obligations imposed by European Union law.

19 Case C-487/12 Vueling Airlines SA, ECLI:EU:C:2014:2232.

20 Case C-70/77 Simmenthal, ECLI:EU:C:1978:139 [1978].

21 Case C-5/14 Kernkraftwerke Lippe-Ems, ECLI:EU:C:2015:354. 


\section{References}

Бойчев, Г. (2003). Правонарушение. София: Юриспрес

Ганев, В. (1990). Учебник по обща теория на правото. Том 1. София: ДФ „7М ГРАФИК"

Гиргинов, Ант. (1999). Коментар на Наказателния кодекс. Обща част. Том I. София: Софи Р

Долапчиев, Н. (1994). Наказателно право. Том 1: Обща част. София: Българска академия на науките

Друмева, Ем. (2008). Конституционно право. София: Сиела

Ненов, Ив. (1992). Наказателно право. Обща част. Книга 1-2. София: Софи Р

Стойнов, Ал. (1999). Наказателно право. Обща част. София: Сиела

Решение № 14 от 4 ноември 2014 г. на Конституционния съд на Република България по конституционно дело № 12/2014 г.

Решение № 10 от 29 май 2018 г. на Конституционния съд на Република България по конституционно дело № 4/2017 г.

Case law

Case C-382/09 S. M. S., ECLI:EU:C:2010:596

Case C-201/10 Urbán, EU:C:2012:64

Case C-255/14 Chmielewski, EU:C:2015:475.

Case C-273/97 Sirdar (Angela Maria) $v$ The Army Board and Secretary of State for Defence [1999], ECR I-7403

Case C-343/09 Afton Chemical, EU:C:2010:419

Joined Cases C-581/10 and C-629/10 Emeka Nelson and Others v Deutsche Lufthansa $A G$, EU:C:2012:657

Case C-283/11 Sky Österreich GmbH v Österreichischer Rundfunk, EU:C:2013:28

Case C-101/12 Herbert Schaible, EU:C:2013:661.

Case C-565/12 LCL Le Crédit Lyonnais, EU:C:2014:190

Case C-210/10 Urbán, EU:C:2012:64, т. 54.

Case C-430/05 Ntionik and Pikoulas, EU:C:2007:410

Case C-210/10 Urbánq EU:C:2012:64 
Case C-81/12 Asociația Accept, EU:C:2013:275

Case C-565/12 LCL Le Crédit Lyonnais EU:C:2014:190

Case C-255/14 Chmielewski, ECLI:EU:C:2015:47

Case 6/64 Flaminio Costa v. E.N.E.L., ECLI:EU:C:1964:66

Case C-487/12 Vueling Airlines SA, ECLI:EU:C:2014:2232

Case C-70/77 Simmenthal, ECLI:EU:C:1978:139 [1978]

Case C-5/14 Kernkraftwerke Lippe-Ems, ECLI:EU:C:2015:354

Case Gäfgen v. Germany, App no 22978/05 (ECtHR 1 June 2010)

Case Siliadin v France, App no 73316/01 (ECtHR 26 July 2005).

Case Sidabras and Others v. Lithuania, App no 50421/08 (ECtHR 23 June 2015.)

Case Oleksandr Volkov v. Ukraine, App no 21722/11 (ECtHR 9 Jan 2013)

Case Riener v. Bulgaria, App no 46343/99 (ECtHR 23 May 2006) 


\title{
Др Вања Валкадинова,
}

Судија Управног суда у Благоевграду,

Предавач на Националном институту правде, Софија

Институту за јавну управу, Софија

Центру за обуку адвоката, Софија, Бугарска

\section{ПРИНЦИП ПРОПОРЦИОНАЛНОСТИ У ПРИМЕНИ САНКЦИЈА И ДРУГИХ МЕРА ДРЖАВНЕ ПРИНУДЕ У БУГАРСКОМ ЗАКОНОДАВСТВУ И У ПРАВУ ЕВРОПСКЕ УНИЈЕ}

\begin{abstract}
Резиме
Пропорционалност као основни принцип захтева да акти јавних власти не утичу на права и легитимне интересе у већој мери него што то налаже сврха издавања одређеног акта. Приликом примене санкција и других мера државне принуде, принцип пропорционалности представља праг ограничења основних права. Санкције морају бити ефикасне, одвраћајуће и пропорционалне. Њихова примена не сме проузроковати последице које су очигледно неусаглашене са предвиђеним циљем. Мере државне принуде, које обезбеђују ефикасну примену санкција, морају да испуне и друге услове, који су блиско повезани са санкцијама. Предмет овог рада је пропорционалност као елемент судске контроле у дефинисању и контроли мера државне принуде у домаћем праву и у праву Европске уније.
\end{abstract}

Кључне речи: пропорционалност, санкција, принудне административне мере, судска контрола пропорционалности. 
